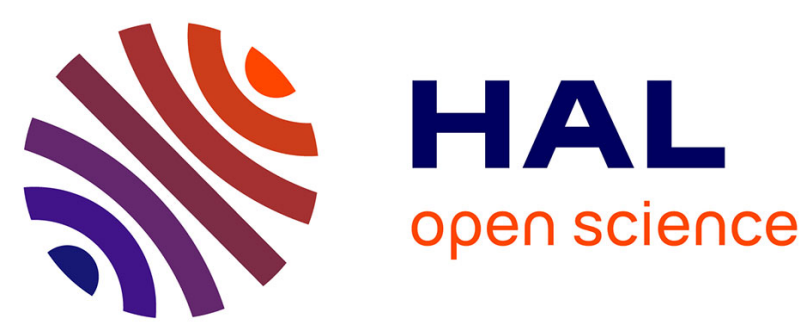

\title{
Two dechlorinated chlordecone derivatives formed by in situ chemical reduction are devoid of genotoxicity and mutagenicity and have lower proangiogenic properties compared to the parent compound
}

Samuel Legeay, Pierre-André Billat, Nicolas Clere, Fabrice Nesslany, Sébastien

Bristeau, Sébastien Faure, Christophe Mouvet

\section{To cite this version:}

Samuel Legeay, Pierre-André Billat, Nicolas Clere, Fabrice Nesslany, Sébastien Bristeau, et al.. Two dechlorinated chlordecone derivatives formed by in situ chemical reduction are devoid of genotoxicity and mutagenicity and have lower proangiogenic properties compared to the parent compound. Environmental Science and Pollution Research, 2018, 25 (15), pp.14313-14323. 10.1007/s11356-0178592-6. hal-02429805

\section{HAL Id: hal-02429805 \\ https://hal.science/hal-02429805}

Submitted on 25 Nov 2021

HAL is a multi-disciplinary open access archive for the deposit and dissemination of scientific research documents, whether they are published or not. The documents may come from teaching and research institutions in France or abroad, or from public or private research centers.
L'archive ouverte pluridisciplinaire HAL, est destinée au dépôt et à la diffusion de documents scientifiques de niveau recherche, publiés ou non, émanant des établissements d'enseignement et de recherche français ou étrangers, des laboratoires publics ou privés. 
Two dechlorinated chlordecone derivatives formed by in situ chemical reduction are

2 devoid of genotoxicity and mutagenicity and have lower proangiogenic properties compared to the parent compound.

4 Legeay Samuel ${ }^{1}$, Billat Pierre-André ${ }^{1}$, Clere Nicolas ${ }^{1}$, Nesslany Fabrice ${ }^{2,3}$, Bristeau Sébastien ${ }^{4}$,

5 Faure Sébastien ${ }^{1}$, Mouvet Christophe ${ }^{5}$

$6{ }^{1}$ Université Bretagne Loire, Université d'Angers, UFR santé, département pharmacie, 16 Bd

7 Daviers, 49100 Angers, France.

$8{ }^{2}$ Institut Pasteur de Lille (IPL), Lille Cedex, France.

$9{ }^{3}$ EA 4483, Université Lille 2, 59000 Lille, France

${ }^{4}$ BRGM, Laboratory Division, 3 Av. Claude Guillemin, 45060 Orléans, Cedex 2, France

${ }^{5}$ BRGM, Water, Environment and Ecotechnologies Division, 3 Av. Claude Guillemin, 45060

Orléans, Cedex 2, France

DOI : $10.1007 / \mathrm{s} 11356-017-8592-6$

$\underline{\text { Address for correspondence: }}$

Christophe Mouvet

3 Av. Claude Guillemin, 45060 Orléans, Cedex 2, France

Email: c.mouvet@brgm.fr

Tel: (0)2 38643908

Fax: (0)2 38643446

\section{ACKNOWLEDGEMENTS:}

The results presented here were obtained through financing by the French Ministry of Environment, General directorate for risk prevention (action F of the 2015 grant program MEDDE/BRGM).

KEY WORDS: In situ chemical reduction, chlordecone, dechlorination, genotoxicity, mutagenicity, angiogenesis

Abstract: 217 words; 1 figure; 6 tables; Text: 4537 words; 20 pages; 45 references 
Author version

\section{ABSTRACT}

Chlordecone (CLD) is a chlorinated hydrocarbon insecticide, now classified as a persistent organic pollutant. Several studies have previously reported that chronic exposure to CLD leads to hepatotoxicity, neurotoxicity, raises early child development and pregnancy complications and increases the risk of liver and prostate cancer. In Situ Chemical Reduction (ISCR) has been identified as a possible way for the remediation of soils contaminated by CLD. In the present study, the objectives were: (i) to evaluate the genotoxicity and the mutagenicity of two CLD metabolites formed by ISCR, CLD-5a-hydro or CLD-5-hydro (5a- or 5- according to CAS nomenclature; CLD-1Cl) and tri-hydroCLD (CLD-3Cl), and (ii), to explore the angiogenic properties of these molecules. Mutagenicity and genotoxicity were investigated using the Ames's technique on Salmonella typhimurium and the in vitro micronucleus micromethod with TK6 human lymphoblastoid cells. The proangiogenic properties were evaluated on the in vitro capillary network formation of human primary endothelial cells. Like CLD, the dechlorinated derivatives of CLD studied were devoid of genotoxic and mutagenic activity. In the assay targeting angiogenic properties, significantly lower microvessel lengths formed by endothelial cells were observed for the CLD-3Cl-treated cells compared to the CLD-treated cells for 2 of the 3 tested concentrations. These results suggest that dechlorinated CLD derivatives are devoid of mutagenicity and genotoxicity and have lower proangiogenic properties than CLD. 
Author version

\section{INTRODUCTION}

Chlordecone (CLD, decachlorooctahydro-1,3,4-metheno-2H-cyclobuta[c,d]pentalen2-one, CAS No: 143-50-0), also named Kepone, is an organochlorine insecticide that has been intensively used in banana plantations of the French West Indies, and to a lesser extent in Cameroon, Ivory Coast, Equator, Honduras, Nicaragua and Panama (Fintz 2009; OPECST 2009; Joly 2010) and in the USA until 1976 as well as in Asia (UNEP/POPS/POPRC 2007). CLD is highly persistent in the environment and considered by the Stockholm Convention as a persistent organic pollutant (POP). From 1973 to 1993, approximately 300 tons of CLD have been applied in the French West Indies (FWI) (PNAC 2008 - 2010). As a result, 20 to 30,000 ha have been contaminated, representing up to $25 \%$ of the total agricultural surface of the FWI (PNAC 2008 - 2010). This pollution is bound to last for centuries if nothing is done to lower soil contamination (Cabidoche et al. 2009). Indeed, despite its use being banned since 1993 in France, CLD is still present in soil, water and consequently in food in FWI. As a consequence, inhabitants of FWI can be chronically exposed to CLD through local food and drinking water. This is a major health issue because CLD is classified as possibly carcinogenic for human (group 2B) by the international agency for research on cancer (IARC). Moreover, it has been reported that exposure to CLD lead to hepatotoxicity and increases the risk of cancer in rats (Reuber 1979; Sirica et al. 1989; Faroon et al. 1995). In addition, long term exposure to CLD has been reported to be associated with a neurotoxicity, a raise of early child development and pregnancy complications and an increased risk of liver and prostate cancer in Human (Multigner et al. 2010; Dallaire et al. 2012; Kadhel et al. 2014; Multigner et al. 2016).

CLD is considered as an endocrine disruptor notably by interacting with the estrogen

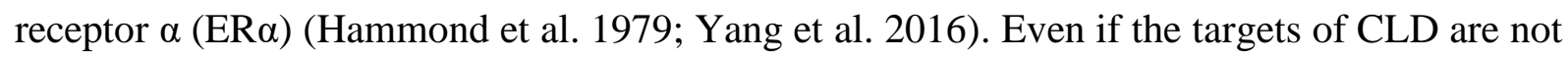
fully identified, this mechanism could explain in part its carcinogenicity and its developmental toxicity (Multigner et al. 2010; Clere et al. 2012). Indeed, pharmacological blockade of ER $\alpha$ has been identified to prevent CLD-induced angiogenesis, an endothelial process involved in tumor growth (Clere et al. 2012).

In situ chemical reduction (ISCR) has been identified as a promising way for the remediation of soils contaminated by CLD (Clostre et al. 2010). ISCR (United States Patent 2000) is based on treatment cycles of alternated strongly reducing conditions with oxidizing conditions. The efficiency of ISCR has already been proven in remediation of soils contaminated by various pesticides (Phillips et al. 2004; Phillips et al. 2005; Phillips et al. 2006; Kim et al. 2010). 
The potential of chemical reduction for remediation of CLD contaminated soil has been investigated in laboratory pilot-scale $80 \mathrm{~kg}$ mesocosms for andosol, ferralsol and nitisol from FWI banana plantations. After a 6-month treatment, eleven CLD-dechlorinated transformation products, from mono- to penta-dechlorinated, were identified in all three soil types. The CLD soil concentration was lowered by $74 \%$ in nitisol, $71 \%$ in ferralsol and $22 \%$ in andosol (Mouvet et al. 2016a).

The efficiency of ISCR has been confirmed at field scale (Mouvet et al. 2016b) leading to perspectives for large scale application of the process. The two main transformation products resulting from ISCR applied to CLD contaminated soils have been made available as analytical standards by dedicated synthesis (Mouvet et al. 2016c). The major transformation product has been established to be a mono-dechlorinated CLD (CLD-1Cl), the CLD-5a-hydro or CLD-5hydro (5a- or 5- according to CAS nomenclature, the data available do not enable the position of dechlorination to be more precisely defined) (Belghit et al. 2015). This single CLD-1Cl represents $50 \%$ of the cumulated relative peak areas (measured by GC/MS) of the eleven transformation products identified after the 27-day ISCR treatment of an alluvial soil (Mouvet et al. 2016b). The second most important degradation product is known to be a tri-dechlorinated $\mathrm{CLD}$ (CLD-3Cl, the position on the carbon skeleton of the $3 \mathrm{Cl}$ replaced by $\mathrm{H}$ remains unknown Belghit et al. 2015) that represents $13 \%$ of the cumulated relative peak areas of all transformation products (Mouvet et al. 2016b). Studying two degradation products representing $63 \%$ of the cumulated relative peak areas of the eleven transformation products was considered appropriate to determine the efficiency (from a toxicological standpoint) of the ISCR relative to the initial CLD concentration.

Based on i) the proven potential of ISCR for soil remediation, ii) the availability of analytical standards of the two main CLD derivatives formed by ISCR, and iii) the lack of data on the toxicity of these compounds, the aim of the present study was to compare the genotoxicity and the mutagenicity of CLD, CLD-1Cl and CLD-3Cl, and to evaluate their proangiogenic properties on endothelial cells. 
Author version

\section{MATERIAL AND METHODS}

Chemicals and reagents:

Chlordecone, purity $93.5 \%$, was purchased from Dr Ehrenstorfer (reference C11220000). CLD-5a-hydro or CLD-5-hydro (5a- or 5- according to CAS nomenclature; CLD-1Cl) and the main tri-hydroCLD (CLD-3Cl) formed by ISCR were synthesized by Alpha-Chimica (AlphaChimica, Châtenay-Malabry. FRANCE) with a purity of $92.6 \%$ and $88.6 \%$, respectively. GC/MS/MS show the impurities to be other CLD dechlorinated derivatives. The purity of the tested compounds was taken into account for the preparation of each concentration investigated.

Penicillin, sodium pyruvate, streptomycin, 3-[4,5-dimethylthiazol-2-yl]-2,5diphenyltetrazolium bromid (MTT), biotin, histidine, and $\mathrm{NaCl}$ were purchased from SigmaAldrich (Saint-Quentin Fallavier, France), dimethylsulfoxide, ethanol, L-glutamine, $\mathrm{KCl}$ and $\mathrm{NaOH}$ were purchased from Merck (Darmstadt, Germany), glucose-6-phosphate and NADP was purchased from Roche (Mannheim, Germany) and top agar from Oxoid (Basingstoke, UK).

Mitomycin C (CAS Registry Number: 50-07-7), benzo[a]pyrene (CAS Registry Number: 5032-8), sodium azide (CAS Registry Number: 26628-22-8) and 9-amino-acridine (CAS Registry Number: 90-45-9) were provided by Sigma-Aldrich (Sigma-Aldrich Chemical Co.; L'Isle d'Abeau Chesnes, France). 2-anthramine (CAS Registry Number: 613-13-8) was supplied by Sigma-Aldrich GmbH (Steinheim, Germany) and 2-nitrofluorene (CAS Registry Number: 60757-8) was provided by Merck (Darmstadt, Germany).

\section{Cell culture:}

TK6 human lymphoblastoid cells obtained from ECACC (Porton Down, Salisbury, UK) were maintained in RPMI 1640 medium supplemented with 200 units $/ \mathrm{mL}$ penicillin, $50 \mu \mathrm{g} / \mathrm{mL}$ streptomycin, $2.5 \mu \mathrm{g} / \mathrm{mL}$ amphotericin B, $200 \mu \mathrm{g} / \mathrm{mL}$ L-glutamine, $200 \mu \mathrm{g} / \mathrm{mL}$ sodium pyruvate and $10 \%$ (v/v) heat inactivated horse serum (RPMI 10 medium) at $37{ }^{\circ} \mathrm{C}$ in humidified atmosphere containing $5 \% \mathrm{CO}_{2}$. They have a stable caryotype (47, XY, 13+) and have a 16-18 hour doubling time. Each new batch of cells was tested to confirm the absence of mycoplasma contamination (Mycoalert mycoplasma detection kit. Cambrex Bio Science Rockland, inc).

Human umbilical venous endothelial cells (HUVEC) obtained from male newborns were purchased from Lonza (CC2517) and grown in plastic flasks in EBM-2 medium (Lonza, CC3162) containing 10\% of heat-inactivated fetal bovine serum (FBS, Gibco, 10270-106) at 
Author version

$37{ }^{\circ} \mathrm{C}$ in humidified atmosphere containing $5 \% \mathrm{CO}_{2}$. HUVEC were used between the second and fourth passage.

\section{Metabolic activation system used for genotoxicity:}

After enzymatic induction with Arochlor 1254, rat liver S9 was prepared according to Ames et al. (1975) and Maron and Ames (1983) (Ames et al. 1975; Maron and Ames 1983).

In the Ames test, S9-mix contained per mL: $0.1 \mathrm{~mL}$ of $\mathrm{S} 9,0.02 \mathrm{~mL}$ of $\mathrm{MgCl}_{2} 0.4 \mathrm{M}, 0.02 \mathrm{~mL}$ of $\mathrm{KCl} 1.65 \mathrm{M}, 0.5 \mathrm{~mL}$ of phosphate buffer $0.2 \mathrm{M}$ (pH 7.4), $0.04 \mathrm{~mL}$ of NADP 0.1 M, 0.005 $\mathrm{mL}$ of glucose-6-phosphate $1 \mathrm{M}$ and $0.315 \mathrm{~mL}$ of $\mathrm{H}_{2} \mathrm{O}$ and was used at $50 \%$ during treatment, i.e. $5 \%$ of $\mathrm{S} 9$ in final concentration.

In the in vitro micronucleus assay, S9-mix contained per mL: $0.4 \mathrm{~mL}$ of S9, $0.2 \mathrm{~mL}$ of $150 \mathrm{mM}$ $\mathrm{KCl}, 0.2 \mathrm{~mL}$ of $25 \mathrm{mg} / \mathrm{mL}$ NADP and $0.2 \mathrm{~mL}$ of $180 \mathrm{mg} / \mathrm{mL}$ glucose-6-phosphate and was used at $5 \%$, giving $2 \%$ of S9 in final concentration.

Except S9, all cofactors were filtered through a sterilizing membrane before use.

\section{Bacterial mutagenicity test on Salmonella typhimurium His- using Ames's technique:}

CLD, CLD-1Cl and CLD-3Cl were tested in strains TA1537, TA98, TA100 and TA102 at the highest final dose of $200 \mu \mathrm{g} /$ plate expressed as pure compound (using an initial concentrated solution in DMSO at $2 \mathrm{mg} / \mathrm{mL}$ ), as well as 5 lower doses (from 100 to $1 \mu \mathrm{g} / \mathrm{plate}$ ). The test was performed using the standard plate incorporation method (Ames et al. 1975) both with and without S9 by microsomal liver fractions. A triplicate test for each experimental point was made and the plates were then kept at $37{ }^{\circ} \mathrm{C}$ for $48 \mathrm{~h}$, after which the number of revertant colonies was determined for each plate.

Appropriate positive reference controls were also performed (without S9: TA1537: 9-aminoacridine $50 \mu \mathrm{g} /$ plate, TA98 2-nitro fluorene $2 \mu \mathrm{g} /$ plate, TA100 sodium azide $1 \mu \mathrm{g} / \mathrm{plate}$ and TA102 mitomycin C $0.125 \mu \mathrm{g} /$ plate - with liver S9: TA1537, TA98 and TA100 2-anthramine $2 \mu \mathrm{g} /$ plate and TA102 benzo[a]pyrene $2 \mu \mathrm{g} /$ plate).

A response is considered positive in the assay if a dose-response relationship is observed on 3 consecutive doses with, for the highest increase, an induction ratio greater than or equal to 3 (strain TA1537) or 2 (strains TA98, TA100 and TA102). In parallel, data were analyzed by 
Author version

means of Dunnett's method (Mahon et al. 1989) allowing the comparison of the mean value for each dose to the mean value for the corresponding solvent control.

\section{In vitro micronucleus assay in micromethod with TK6 human lymphoblastoid cells:}

The procedure for this micromethod for in vitro micronucleus assay has been previously detailed (Nesslany et al. 2009). Main points are reminded below:

The assay was carried out with and without S9 microsomal liver. CLD, CLD-1Cl and CLD-3Cl were dissolved in DMSO at the initial concentration of $100 \mathrm{mg} / \mathrm{mL}$, giving the final concentration of $1000 \mu \mathrm{g} / \mathrm{mL}$ when added at $1 \%$ in culture medium.

Exponentially growing TK6 cells were treated either for $3 \mathrm{~h}$ (with or without S9-mix) followed by a $24 \mathrm{~h}$ recovery time before harvesting or during $27 \mathrm{~h}$, corresponding to $c a 1.5$ cell cycles, immediately followed by the harvest (without S9-mix only). Each treatment was performed in duplicate and was coupled to a cytotoxicity assessment using a MTT (3-[4,5-dimethylthiazol2-gl]-2,5 diphenyl tetrazolium bromid, Sigma) colorimetric method (Borenfreund et al. 1988). At each step, microplates were centrifugated $6 \mathrm{~min}$ at $1000 \mathrm{rpm}$ and the supernatant discarded by gentle pouring off.

The cells were first washed $(0.2 \mathrm{~mL}$ culture medium RPMI $+1 \%$ pluronic acid $10 \%$ solution $)$ and gently resuspended before hypotonic treatment ( 4 min with $0.15 \mathrm{~mL}$ RPMI 0 diluted $1 \mathrm{vol}$ $/ 1 \mathrm{vol}$ in distilled water $+1 \%$ pluronic acid). Then, a volume of $40 \mu \mathrm{L}$ ethanol/acetic acid (3 vol $/ 1$ vol) was added in each well for pre-fixation step. Afterwards, the cells were fixed by addition of $0.15 \mathrm{~mL}$ ethanol/acetic acid (3 vol / $1 \mathrm{vol}$ ) for at least $10 \mathrm{~min}$. The cells were finally resuspended by drawing and expelling with a Pasteur pipette, dropped onto wet clean glass slides and allowed to dry at room temperature. After at least $12 \mathrm{~h}$, the air-dried slides were stained 10 min with $2 \%$ Giemsa water solution, rinsed, coded and analyzed.

In case of cytotoxicity, the highest concentration was fixed according to the reduction of the MTT incorporation $(\leq 55+/-5 \%)$. At least two lower concentrations were also retained for the genotoxic analysis. Micronuclei, identified according to criteria described by Fenech et al., were analyzed in at least 2000 mononucleated cells for the 3 retained concentrations. The statistical significance of differences between groups was determined using the CHI2-test (Fenech et al. 2003). Positive controls were included in each corresponding treatment schedule: mitomycin C without S9-mix at $0.5 \mu \mathrm{g} / \mathrm{mL}$ (3-h treatment) or $0.2 \mu \mathrm{g} / \mathrm{mL}$ (27-h treatment 
Author version

205

206

207

208

209

210

211

212

213

214

215

216

217

218

219

220

221

without S9-mix), griseofulvin (aneugenic mode of action) at $5 \mu \mathrm{g} / \mathrm{mL}$ (27-h treatment without S9-mix) and cyclophosphamide at $5 \mu \mathrm{g} / \mathrm{ml}$ with liver S9-mix.

\section{In vitro capillary network formation on ECM gel:}

HUVEC were seeded at a density of 10,000 cells per well. Each well was precoated with ECM gel (Sigma-Aldrich, E1270). Briefly, $10 \mu \mathrm{L}$ of ECM gel was added into a 15-well angiogenesis plate (Ibidi ${ }^{\circledR}$, Biovalley ${ }^{\circledR} 81506$ ) and allowed to solidify for approximately 45 min at $37^{\circ} \mathrm{C}$. Then, cells were incubated with medium containing $10 \%$ of FBS and either in the absence or presence of CLD, CLD-1Cl or CLD-3Cl used at the three relevant concentrations $10^{-11} \mathrm{M}$ (a plasma concentration common in exposed humans) (Heath 1978; Taylor 1982) (3.10-8 M (a concentration found in drinking water) (Badach et al. 2000) and $10^{-9} \mathrm{M}$ (intermediary concentration). Tube formation was examined by phase-contrast microscopy (MOTIC AE21) after $24 \mathrm{~h}$ of incubation and the average length of capillaries was quantified using ImageJ software. Data are presented as mean \pm Standard Error of the Mean, $\mathrm{n}$ represents the number of independent experiments. Statistical analyses were performed by a Student $t$ test. $\mathrm{p}<0.05$ was considered to be statistically significant. 


\section{RESULTS}

1. Ames test on Salmonella typhimurium strains TA1537, TA98, TA100 and TA102

CLD and its dechlorinated derivatives, i.e. CLD-1Cl and CLD-3Cl, induced neither biologically nor statistically significant changes in the number of revertants in all four Salmonella typhimurium strains TA1537, TA98, TA100 and TA102 tested either in the absence or in the presence of the metabolic activation system. Thus, CLD mono- or tri-dechlorination does not modify the mutagenic potential of CLD (Tables 1 to 3). In return, noteworthy, each of the substances had distinct behaviors in terms of bacteriostatic activity. Indeed, while the highest interpretable doses of CLD were set at 30, 10 and even $3 \mu \mathrm{g} / \mathrm{plate}$, CLD-1Cl was not or moderately toxic up to the doses ranging from 30 to $200 \mu \mathrm{g} /$ plate. Finally, no bacteriostatic activity was observed in any of the four strains of Salmonella typhimurium treated with CLD$3 \mathrm{Cl}$ up to the highest dose tested of $200 \mu \mathrm{g} /$ plate. Even if the cytotoxicity assessment performed during the genotoxicity assays aimed at providing information about the reliability of these tests and at setting the range of doses to be actually tested, as they were obtained under the same experimental conditions, it was deemed interesting to compare the cytotoxicity of CLD and both its dechlorinated derivatives, as determined in these tests. Indeed, the data highlight a clear difference in terms of cytotoxicity in bacteria during the Ames test (with for instance, during the assays without metabolic activation, the highest analyzable doses of 10, 30 and > 200 $\mu \mathrm{g} /$ plate for CLD, CLD-1Cl and CLD-3Cl, respectively). The following order of cytotoxic potential on Salmonella typhimurium was therefore observed: CLD > CLD-1Cl > CLD-3Cl.

2. In vitro micronucleus assay with TK6 human lymphoblastoid cells

The positive controls (mitomycin C in both treatments without rat liver S9-mix, griseofulvin in the continuous treatment without S9-mix, and cyclophosphamide in presence of S9-mix) induced statistically and biologically significant increases in the number of micronucleated TK6 cells as expected, with values comparable to the ones usually observed in the laboratory.

First, it is interesting to note that the 3 substances, i.e. CLD and its dechlorinated derivatives, did not have similar cytotoxicity (Tables 4 to 6). Indeed, in the short-term treatment without metabolic activation, the highest concentrations leading to acceptable level of toxicity were of $31.25 \mu \mathrm{g} / \mathrm{mL}\left(6.37 .10^{-5} \mathrm{M}\right), 62.5 \mu \mathrm{g} / \mathrm{mL}\left(1.37 .10^{-4} \mathrm{M}\right)$ and $125 \mu \mathrm{g} / \mathrm{mL}\left(3.23 .10^{-4} \mathrm{M}\right)$ for CLD, CLD-1Cl and CLD-3Cl, respectively. In the long term treatment, the highest concentrations reached $31.25 \mu \mathrm{g} / \mathrm{mL}$ for both CLD and CLD-1Cl $\left(6.37 .10^{-5} \mathrm{M}\right.$ and $6.85 .10^{-5} \mathrm{M}$, respectively) and $62.5 \mu \mathrm{g} / \mathrm{mL}\left(1.61 .10^{-4} \mathrm{M}\right)$ for CLD-3Cl. In the treatment with metabolic activation, the top 
concentrations were set at $62.5 \mu \mathrm{g} / \mathrm{mL}\left(1.27 .10^{-4} \mathrm{M}\right.$ and 1.37.10-4 $\left.\mathrm{M}\right)$ for both CLD and CLD$1 \mathrm{Cl}$ and $125 \mu \mathrm{g} / \mathrm{mL}\left(3.23 .10^{-4} \mathrm{M}\right)$ for CLD-3Cl.

Furthermore, no genotoxic activity was noted in the assays with and without rat liver S9-mix using both a short and a long-term treatment (Table 4). Indeed, no biologically significant increases in the incidence of TK6 human lymphoblastoid micronucleated cells were observed on the whole range of concentrations analyzed of CLD and its derivatives: CLD induced 2 to 11.5 micronucleates/2000 mononucleated TK6 cells in the short treatment without metabolic activation, 1 to 7 micronucleates/2000 mononucleated TK6 cells in the continuous treatment without metabolic activation and 3 to 7 micronucleates/2000 mononucleated TK6 cells in the short treatment with rat liver S9-mix compared to 7, 9 and 2 micronucleates/2000 mononucleated TK6 cells in their respective solvent controls. CLD-1Cl induced in the shortterm treatment without metabolic activation 3 to 4 micronucleated/2000 mononucleated TK6 cells vs. 7 in the solvent control, 5 to 8 micronucleated/2000 mononucleated TK6 cells $v s .9$ in the continuous treatment and 0 to 5 micronucleates/2000 mononucleated TK6 cells $v s .2$ for the solvent control. Finally, in the short-term and continuous treatments without metabolic activation and in the short-term treatment with rat liver S9, CLD-3Cl induced 1 to 7, 4 to 13 and 2 to 4 micronucleates /2000 mononucleates TK6 cells $v s .8,7$ and 2 in the corresponding negative controls. Dechlorinated derivatives CLD-1Cl and CLD-3Cl, like CLD, were clearly devoid of genotoxicity.

\section{Evaluation of the proangiogenic properties in vitro}

After $24 \mathrm{~h}$ incubation, CLD was able to increase capillary length formed by HUVEC compared to non-treated cells for the three tested concentrations (at $10^{-11} \mathrm{M}, 179.51 \pm 13.47 \%, \mathrm{p}<0.001$; at $10^{-9} \mathrm{M}, 150.53 \pm 8.41 \%, \mathrm{p}<0.01$; and at $5.10^{-8} \mathrm{M}, 154.88 \pm 7.37 \%, \mathrm{p}<0.001$; Fig.1, A, B and C). The mono-dechlorinated CLD derivative CLD-1Cl also exerted proangiogenic properties on HUVECs in culture on ECM gel for the three concentrations compared to control cells (at 10$11 \mathrm{M}, 147.68 \pm 12.42 \%, \mathrm{p}<0.05$; at $10^{-9} \mathrm{M}, 136.08 \pm 7.84 \% \mathrm{p}<0.05$; and at $5.10^{-8} \mathrm{M}$, 145.94 $\pm 16.74 \%$, p<0.05; Fig.1, A, B and C). However, the tri-dechlorinated CLD derivative CLD-3Cl did not significantly increase endothelial capillary formation compared to control cells (at $10^{-11} \mathrm{M}, 131.10 \pm 5.96 \%, \mathrm{p}=0.071$; at $10^{-9} \mathrm{M} 121.06 \pm 10.84 \%, \mathrm{p}=0.169$; and at $5.10^{-8} \mathrm{M}$, $132.10 \pm 5.73 \%, \mathrm{p}=0.068$, Fig. 1, A, B and C). Moreover, the mean capillary length formed by HUVEC was significantly lower after CLD-3Cl treatment compared to CLD treatment with two of the three tested concentrations (at $10^{-11} \mathrm{M}, 179.51 \pm 13.47 \%$ vs $131.10 \pm 5.96 \%$, $\mathrm{p}<0.05$; at $10^{-9} \mathrm{M}, 150.53 \pm 8.41 \%$ vs $121.06 \pm 10.84 \%, \mathrm{p}=0.113$; and at $5.10^{-8} \mathrm{M}, 154.88 \pm 7.37 \%$ vs 
Author version

$287 \quad 132.10 \pm 5.73 \%, \mathrm{p}<0.05$, Fig. 1 , A and C). No significant statistical difference was found between 288 all the other conditions.

289

290

291 
Author version
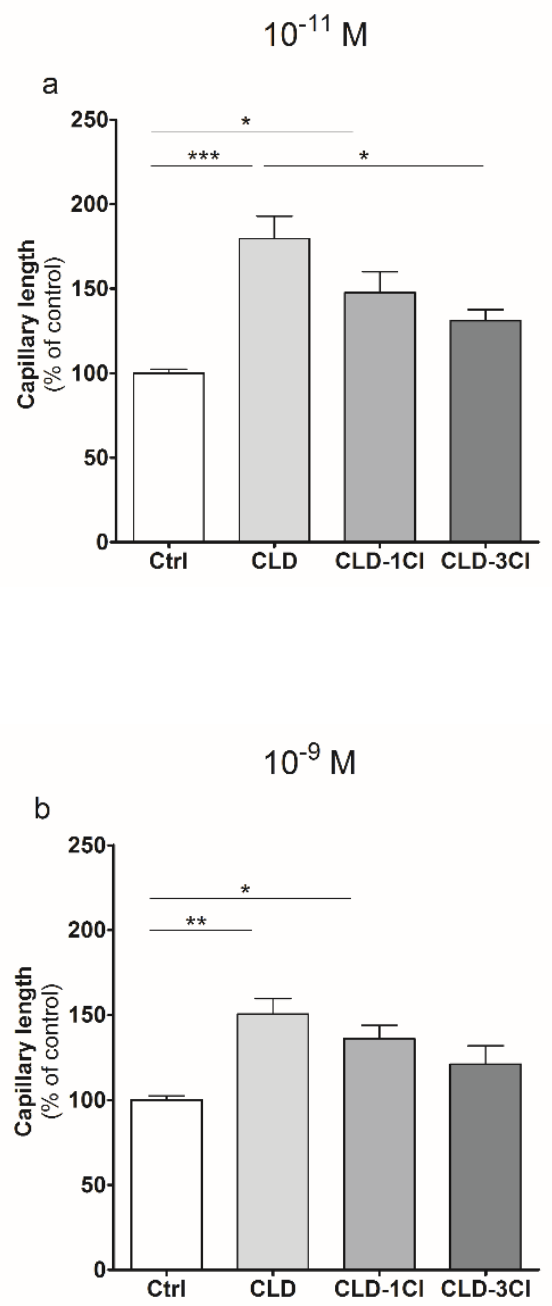

$$
5.10^{-8} \mathrm{M}
$$

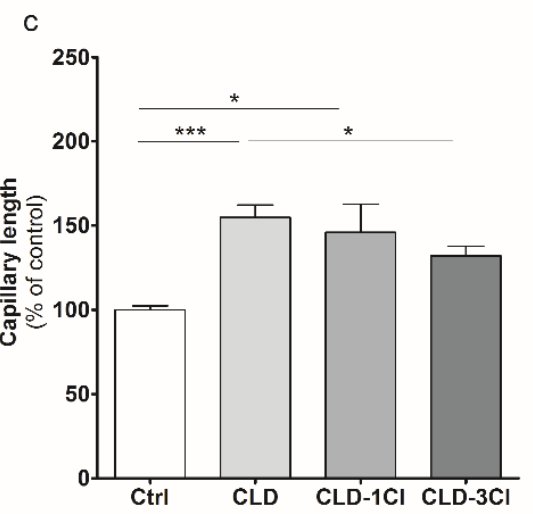

Figure 1: Capillary length formed by HUVEC treated with CLD, CLD-1Cl and CLD- 
Author version

\section{DISCUSSION}

In order to compare the mutagenicity of CLD-1Cl and CLD-3Cl with CLD, the Ames test has been performed both with and without metabolic activation, on four different Salmonella typhimurium strains TA1537, TA98, TA100 and TA102 able of demonstrating genetic events leading to mutagenicity such as frameshift or base pair substitution. This test did not evidence any mutagenic effect of CLD up to the highest dose tested of $200 \mu \mathrm{g} / \mathrm{plate}$. These results are in agreement with those from Schoeny R.S. et al. (1979) who also concluded to the lack of mutagenicity of CLD on Salmonella typhimurium strains TA1535, TA1537, TA98 and TA100 (Schoeny et al. 1979). In the same way, both CLD derivatives, i.e. CLD-1Cl and CLD$3 \mathrm{Cl}$ did not demonstrate any mutagenic activity in this bacterial test system.

Furthermore, CLD induced no chromosomal aberration as demonstrated in the in vitro micronucleus test performed on human lymphoblastoid TK6 cells. These first results are rather in accordance with those generally observed with CLD which is considered to be a nongenotoxic carcinogen (Reuber 1979); for instance, following Ikegwuonu and Mehendale (1991), CLD induced a low level of unscheduled DNA synthesis in the hepatocytes of rats pretreated with $10 \mathrm{mg} / \mathrm{kg}$ b.w. CLD (Ikegwuonu and Mehendale 1991). Only DNA strand breaks were reported in this study. Chlordecone was also found to increase induced ssDNA breaks in isolated human and rat testicular cells as measured by alkaline filter elution but exclusively at high concentrations (300 to $1000 \mu \mathrm{M}$ ), an exposure that was associated with some toxicity in both cell lines (Bjørge et al. 1996).

Dechlorinated derivatives CLD-1Cl and CLD-3Cl were also devoid of genotoxicity meaning that the ISCR process does not lead to degradation products of concern regarding these endpoints.

Most interestingly, a noteworthy difference in terms of toxicity was clearly shown in mutagenicity tests. The following order of toxicity to cells in Ames/micronucleus tests can be established: $\mathrm{CLD}>\mathrm{CLD}-1 \mathrm{Cl}>\mathrm{CLD}-3 \mathrm{Cl}$ that may suggest that dechlorinated CLD derivativesare probably less toxic than CLD. Toxicity mechanisms of CLD have been well established on in vitro eukaryotic cultured cells (End et al. 1981). Briefly, these authors reported that CLD was able to inhibit mitochondrial oxidative phosphorylation and associated $\mathrm{Ca}^{2+}$ transport in neuronal cells. Thus, oxidative stress would be, in part, responsible for the toxicity of CLD but studies evaluating the CLD-induced oxidative stress and the dechlorinated CLD derivatives mechanism of toxicity are now needed. 
Angiogenesis is a critical step for tumor growth and is considered as a pre-requisite for the rapid expansion of macroscopic tumors (Carmeliet and Jain 2011). Furthermore, Clere et $a l$. has already evidenced a CLD-induced proangiogenic effect for two concentrations, 5.10-8 $\mathrm{M}$, a plasmatic value of CLD which is associated with an increased risk of cancer and $2.10^{-11}$ M, a concentration of CLD approximately found in drinking water (Clere et al. 2012). Our data indicating that CLD and CLD-1Cl have in vitro proangiogenic effects for the concentrations $10^{-11} \mathrm{M}, 10^{-9} \mathrm{M}$, and $5.10^{-8} \mathrm{M}$ confirm the previous published data for CLD and extend the observation to CLD-1Cl. Most interestingly, the tri-dechlorinated derivative CLD-3Cl did not exhibit proangiogenic effects and exert a capillary formation significantly lower than CLD for $10^{-11} \mathrm{M}$ and $5.10^{-8} \mathrm{M}$.

These results indicate that CLD dechlorination reduces the CLD proangiogenic properties once $3 \mathrm{Cl}$ have been replaced by $\mathrm{H}$. The replacement of $1 \mathrm{Cl}$ by $\mathrm{H}$ does not have a statistically significant effect. The replacement of $2 \mathrm{Cl}$ by $\mathrm{H}$ might have an effect but an analytical standard of didechlorinated CLD was not available for this study. Mechanisms responsible for the decrease of the proangiogenic effect by CLD dechlorination remain unknown. It has been demonstrated that pharmacological blockade of ER $\alpha$ or a silencing of ER $\alpha$ in endothelial cells prevent the CLD-induced angiogenesis both in vitro with HUVECs in culture on ECM gel ${ }^{\circledR}$ and in vivo with an ECM gel ${ }^{\circledR}$ plug used in mice (Clere et al. 2012). Regarding these data, it would be interesting to estimate the presence or the absence of possible interactions between these two CLD dechlorinated derivatives and ER $\alpha$ in order to evaluate their estrogenicity.

As the implementation of the standard step-wise approach using a basic battery of in vitro genotoxicity tests, led to clear negative results, it can be concluded that the three substances have no genotoxic potential and thus, no carcinogenic potential through a genotoxic mode of action is expected. The epigenetic mode of action was not specifically addressed.

The only referenced paper comparing the toxic effects of CLD and some of its alteration products relates to isolated rat liver mitochondria. It shows the following order of potency: CLD $>$ CLD-1Cl >> CLD-2Cl (Soileau and Moreland 1983). The monodechlorinated-CLD (CLD$1 \mathrm{Cl}$ ) considered, with the $\mathrm{Cl}$ in position $5 \mathrm{~b}$ (according to CAS nomenclature) substituted by an $\mathrm{H}$ atom, is however different from the one studied here, the 5a- or 5-hydro-CLD. As for the didechlorinated-CLD (CLD-2Cl) studied by Soileau and Moreland, it does not correspond to a level of CLD dechlorination considered in our work. 
In another paper aiming at the determination of CLD dechlorination products in finfish, oysters, and crustaceans, the authors (Carver and Griffith 1979) report that the acute toxicity in mysid shrimp of CLD-1Cl is approximately equal to that of CLD, while CLD-2Cl appears to be less acutely toxic by at least an order of magnitude. The source of these data is however not specified, nor is the position of dechlorination of the compounds studied. With respect to the monodechlorinated-CLD, the position of dechlorination is likely to be the same as that of the work by Soileau and Moreland, since limited choice seemed to have been offered to the research laboratories at that time (Soileau and Moreland 1983).

Even though we addressed a monodechlorinated-CLD different from that of Soileau and Moreland and probably also from the one reported by Carver and Griffith, these 3 sets of observations point at a very consistent trend for CLD: toxicity decreases as the level of dechlorination increases. The fact that the trend is observed whatever the position of dechlorination in the CLD-1Cl reinforces the trend itself.

When considering the overall benefit of ISCR, the CLD derivatives other than the 2 studied here must be taken into consideration. Based on the trend supported by 3 independent studies (the present work, Carver and Griffith 1979; Soileau and Moreland 1983), the tetra- and pentadechlorinated-CLD identified in soils (Mouvet et al. 2016b) and water (Belghit et al. 2015) treated by chemical reduction are therefore most likely to be less toxic than the tridechlorinatedCLD, much less than the monodechlorinated-CLD, and far less than the parent compound. Knowing also that the tetra- and pentadechlorinated CLD are formed by ISCR to a much lesser extent than the mono and tridechlorinated-CLD, it can be assumed that the overall suite of CLD dechlorination products formed by chemical reduction is less toxic than CLD. Nevertheless, experimental studies are needed to further explore and confirm or infirm such properties in a living model. The protein-ligand interactions leading to the binding of the main CLD derivatives to estrogen receptors deserve also to be studied. CLD has been shown to be significantly more efficacious for $\mathrm{ER} \alpha$ than for $\operatorname{Er} \beta$, and significant differences appear between chemicals (Delfosse et al., 2014). Such study would notably enable structure-based computational methods that can be used in risk assessment (Delfosse et al. 2014).

\section{CONCLUSION}


Author version

395

396

397

398

399

400

401

402

403

404

405

406

407

408

409

410

411

412

413

414

415

416

417

418

419

CLD and its two derivatives studied here, a mono- and a tri-dechlorinated, induced neither chromosomal aberrations nor mutagenic activity meaning that dechlorination of CLD by ISCR process does not lead to degradation products of concern regarding these endpoints.

Furthermore, the present study demonstrated that CLD-dechlorinated derivatives are devoid of genotoxicity and mutagenicity and have lower proangiogenic properties than CLD. Thus, these CLD derivatives are probably less toxic than CLD.

In view of the major environmental and health issue that soil contamination by CLD represents in the FWI, any possible way of lowering permanently the CLD soil concentrations and the exposure levels of inhabitants is of major interest. So far, ISCR is the only proven way to achieve such a goal. Sequestrating CLD in the soil by adding compost is efficient in lowering plant contamination and leaching to groundwaters. This positive effect has however not been proven to last more than 6 months (Woignier et al. 2012; Woignier et al. 2013). On another hand, public authorities are managing the contamination, e.g., restricting the marketing of food products contingent (Achard et al. 2007), issuing statutory limitations on human consumption of poultry and other animal food (Journal officiel de la République Française 2005) and banning consumption and commercialization of fish and seafood (Préfecture de la Région Guadeloupe 2010). These advices remain however to be strictly obeyed and they do nothing to solve the issue of ecosystems contamination. A combination of the three strategies aforementioned, and possibly others that remain to be tested, will certainly be required. In the case of ISCR, the present results remove partly one of the obstacles to the application of the process over significant areas in situ.

\section{CONFLICTS OF INTEREST}

The authors declare no competing financial interests 
Author version

\section{REFERENCES}

Achard R, Cabidoche Y-M, Caron A, et al (2007) Contamination des racines et tubercules cultivés sur sol pollué par la chlordécone aux Antilles. Cah PRAM 45-50. http://agritrop.cirad.fr/547718/1/document_547718.pdf. Accessed November $18^{\text {th }}$ 2016.

Ames BN, Mccann J, Yamasaki E (1975) Methods for detecting carcinogens and mutagens with the Salmonella/mammalian-microsome mutagenicity test. Mutat Res 31:347-364.

Badach H, Nazimek T, Kaminski R, Turski W (2000) Organochlorine pesticides concentration in the drinking water from regions of extensive agriculture in Poland. Ann Agric Environ Med AAEM 7:25-28.

Belghit H, Colas C, Bristeau S, et al (2015) Liquid chromatography-high-resolution mass spectrometry for identifying aqueous chlordecone hydrate dechlorinated transformation products formed by reaction with zero-valent iron. Int J Environ Anal Chem 95:93-105. doi: 10.1080/03067319.2014.994615

Bjørge C, Brunborg G, Wiger R, et al (1996) A comparative study of chemically induced DNA damage in isolated human and rat testicular cells. Reprod Toxicol Elmsford N 10:509-519.

Borenfreund E, Babich H, Martin-Alguacil N (1988) Comparisons of two in vitro cytotoxicity assays-The neutral red (NR) and tetrazolium MTT tests. Toxicol Vitro Int J Publ Assoc BIBRA 2:1-6.

Cabidoche Y-M, Achard R, Cattan P, et al (2009) Long-term pollution by chlordecone of tropical volcanic soils in the French West Indies: a simple leaching model accounts for current residue. Environ Pollut Barking Essex 1987 157:1697-1705. doi: 10.1016/j.envpol.2008.12.015

Carmeliet P, Jain RK (2011) Molecular mechanisms and clinical applications of angiogenesis. Nature 473:298-307. doi: 10.1038/nature10144

Carver RA, Griffith FD (1979) Determination of kepone dechlorination products in finfish, oysters, and crustaceans. J Agric Food Chem 27:1035-1037.

Clere N, Lauret E, Malthiery Y, et al (2012) Estrogen receptor alpha as a key target of organochlorines to promote angiogenesis. Angiogenesis 15:745-760. doi: $10.1007 / \mathrm{s} 10456-012-9288-7$

Clostre F, Lesueur-Jannoyer M, Cadiboche Y-M (2010) Rémédiation à la pollution par la chlordécone aux Antilles. Cah PRAM 9-10. http://www.observatoire-eaumartinique.fr/les-outils/base-documentaire/conclusions-de-12019atelier-abremediationa-la-pollution-par-la-chlordecone-aux-antillesbb. Accessed November $18^{\text {th }} 2016$.

Dallaire R, Muckle G, Rouget F, et al (2012) Cognitive, visual, and motor development of 7month-old Guadeloupean infants exposed to chlordecone. Environ Res 118:79-85. doi: 10.1016/j.envres.2012.07.006 
Delfosse V, Grimaldi M, Cavaillès V, et al (2014) Structural and functional profiling of environmental ligands for estrogen receptors. Environ Health Perspect 122:13061313. doi: 10.1289/ehp. 1408453

End DW, Carchman RA, Dewey WL (1981) Neurochemical correlates of chlordecone neurotoxicity. J Toxicol Environ Health 8:707-718. doi: $10.1080 / 15287398109530107$

Faroon O, Kueberuwa S, Smith L, DeRosa C (1995) ATSDR evaluation of health effects of chemicals. II. Mirex and chlordecone: health effects, toxicokinetics, human exposure, and environmental fate. Toxicol Ind Health 11:1-203.

Fenech M, Chang WP, Kirsch-Volders M, et al (2003) HUMN project: detailed description of the scoring criteria for the cytokinesis-block micronucleus assay using isolated human lymphocyte cultures. Mutat Res 534:65-75.

Fintz M (2009) L'autorisation du Chlordécone en France 1968-1981, Rapport AFSSET; http://www.observatoirepesticides.fr/upload/bibliotheque/457291400429630296486151015810/autorisation_c hlordecone_france_1968_1981.pdf. Accessed January $3^{\text {rd }}, 2017$.

Hammond B, Katzenellenbogen BS, Krauthammer N, McConnell J (1979) Estrogenic activity of the insecticide chlordecone (Kepone) and interaction with uterine estrogen receptors. Proc Natl Acad Sci U S A 76:6641-6645.

Heath CW (1978) Environmental pollutants and the epidemiology of cancer. Environ Health Perspect 27:7-10.

Ikegwuonu FI, Mehendale HM (1991) Biochemical assessment of the genotoxicity of the in vitro interaction between chlordecone and carbon tetrachloride in rat hepatocytes. $\mathbf{J}$ Appl Toxicol JAT 11:303-310.

Joly PB (2010) La saga du chlordécone aux Antilles françaises. Reconstruction chronologique 1968-2008. Rapport INRA Sens; http://www.observatoirepesticides.fr/upload/bibliotheque/852173530783222242256849728077/saga_chlordec one_antilles_francaises_1968_2008.pdf. Accessed January $3^{\text {rd }}, 2017$.

Kadhel P, Monfort C, Costet N, et al (2014) Chlordecone exposure, length of gestation, and risk of preterm birth. Am J Epidemiol 179:536-544. doi: 10.1093/aje/kwt313

Kim S-C, Yang JE, Ok YS, et al (2010) Accelerated Metolachlor Degradation in Soil by Zerovalent Iron and Compost Amendments. Bull Environ Contam Toxicol 84:459464. doi: 10.1007/s00128-010-9963-6

Mahon G, Green M, Middleton B, et al (1989) Analysis of data from microbial colony assays. In: UKEMS Sub-committee on Guidelines for Mutagenicity Testing Report: Part III Statistical Evaluation of Mutagenicity Test Data. Kirkland DJ, Cambridge, New York: Cambridge University Press, pp 26-65.

Maron DM, Ames BN (1983) Revised methods for the Salmonella mutagenicity test. Mutat Res 113:173-215. 
Mouvet C, Dictor M-C, Bristeau S, et al (2016a) Remediation by chemical reduction in laboratory mesocosms of three chlordecone-contaminated tropical soils. Environ Sci Pollut Res Int. doi: 10.1007/s11356-016-7582-4

Mouvet C, Collet B, Gaude JM, et al (2016b) Décontamination par In Situ Chemical Reduction d'un nitisol et d'un sol alluvionnaire pollués par la chlordécone. Résultats physico-chimiques et agronomiques. Rapport final. BRGM/RP-65462-FR, 188p., 61 ill., 61 tabl., 1 ann. http://infoterre.brgm.fr/rapports/RP-58704-FR.pdf. Accessed October $7^{\text {th }} 2016$.

Mouvet C, Crouzet C, Bristeau S, et al (2016c) Sorption et désorption de la chlordécone et de deux de ses produits de dégradation formés par déchloration réductive. Rapport final. BRGM/RP-65357-FR, 34p., 6 fig., 10 tabl. http://infoterre.brgm.fr/rapports/RP-65357FR.pdf. Accessed October $7^{\text {th }} 2016$.

Multigner L, Kadhel P, Rouget F, et al (2016) Chlordecone exposure and adverse effects in French West Indies populations. Environ Sci Pollut Res Int 23:3-8. doi: $10.1007 / \mathrm{s} 11356-015-4621-5$

Multigner L, Ndong JR, Giusti A, et al (2010) Chlordecone exposure and risk of prostate cancer. J Clin Oncol Off J Am Soc Clin Oncol 28:3457-3462. doi: 10.1200/JCO.2009.27.2153

Nesslany F, Simar-Meintières S, Ficheux H, Marzin D (2009) Aloe-emodin-induced DNA fragmentation in the mouse in vivo comet assay. Mutat Res 678:13-19. doi: 10.1016/j.mrgentox.2009.06.004

OPECST (Office Parlementaire d'Evaluation des Choix Scientifiques et Technologiques ; 2009). Rapport sur les impacts de l'utilisation de la Chlordécone et des pesticides aux Antilles : bilan et perspectives d'évolution, par M. Jean-Yves LE DÉAUT, député et Mme Catherine PROCACCIA, sénateur; http://www.senat.fr/rap/r08-487/r084871.pdf. Accessed January $3^{\text {rd }}, 2017$.

Phillips TM, Lee H, Trevors JT, Seech AG (2004) Mineralization of hexachlorocyclohexane in soil during solid-phase bioremediation. J Ind Microbiol Biotechnol 31:216-222. doi: 10.1007/s10295-004-0139-4

Phillips TM, Lee H, Trevors JT, Seech AG (2006) Full-scale in situ bioremediation of hexachlorocyclohexane-contaminated soil. J Chem Technol Biotechnol 81:289-298. doi: $10.1002 /$ jctb. 1390

Phillips TM, Seech AG, Lee H, Trevors JT (2005) Biodegradation of hexachlorocyclohexane $(\mathrm{HCH})$ by microorganisms. Biodegradation 16:363-392.

PNAC (2008) Plan d'action chlordécone en Martinique et en Guadeloupe: rapport interministériel d'activité (année 2009). http://agriculture.gouv.fr/telecharger/63798?token=aa65f5b7b786198cd89d253f56c23 541.pdf. Accessed October $7^{\text {th }} 2016$.

Reuber MD (1979) The carcinogenicity kepone. J Environ Pathol Toxicol 2:671-686. 
Author version

Schoeny RS, Smith CC, Loper JC (1979) Non-mutagenicity for Salmonella of the chlorinated hydrocarbons aroclor 1254, 1,2,4-trichlorobenzene, mirex and kepone. Mutat Res 68:125-132.

Sirica AE, Wilkerson CS, Wu LL, et al (1989) Evaluation of chlordecone in a two-stage model of hepatocarcinogenesis: a significant sex difference in the hepatocellular carcinoma incidence. Carcinogenesis 10:1047-1054.

Soileau SD, Moreland DE (1983) Effects of chlordecone and its alteration products on isolated rat liver mitochondria. Toxicol Appl Pharmacol 67:89-99.

Taylor JR (1982) Neurological manifestations in humans exposed to chlordecone and followup results. Neurotoxicology 3:9-16.

UNEP/POPS/POPRC.3/10 (2007) Projet d'évaluation de la gestion des risques : chlordécone. http://www.pops.int/documents/meetings/poprc_3/meetingdocs/poprc3_doc/10/K0762 894.F_POPS_POPRC_3_10.pdf. Accessed January $3^{\text {rd }}, 2017$.

Woignier T, Fernandes P, Jannoyer-Lesueur M, Soler A (2012) Sequestration of chlordecone in the porous structure of an andosol and effects of added organic matter: an alternative to decontamination. Eur J Soil Sci 63:717-723. doi: 10.1111/j.13652389.2012.01471.x

Woignier T, Fernandes P, Soler A, et al (2013) Soil microstructure and organic matter: keys for chlordecone sequestration. J Hazard Mater 262:357-364. doi: 10.1016/j.jhazmat.2013.08.070

Yang L, Zhou B, Zha J, Wang Z (2016) Mechanistic study of chlordecone-induced endocrine disruption: Based on an adverse outcome pathway network. Chemosphere 161:372381. doi: 10.1016/j.chemosphere.2016.07.034 